\title{
A SPORTOLÓK TERÜLETI MOZGÁSAI, AVAGY A SPORTOLÓI VÁNDORLÁS ${ }^{1}$
}

\author{
(Migration of Sports People)
}

\section{ÁCS PONGRÁC}

Kulcsszavak:

sportolói vándorlás területi egyenlötlenségek motivációs tényezök

Napjainkban a sport az egyre bövülö szórakoztató ipar része, amely a társadalom homlokterében álló jelenségek közül az egyik leglátványosabb növekedést produkáló terület. A hazai ,sportgazdaság" 2005-ben becsült árbevétele 350 milliảrd forint volt, ami megközelitóleg az akkori GDP 1,7\%-a, vagyis a korábbi évekhez képest jelentốs piacbövülést mutat. Jelen kutatás a sportgazdaság legkisebb egységeivel, a sportolók térbeli mozgásaival foglalkozik. A sportolói migráció valójában térbeli mobilitást jelent, az egyik földrajzi területröl a másik földrajzi terület felé. A tanulmány célja, a sportolói vándorlás fogalmainak tisztázásán túl, saját empirikus adatbázis segitségével bemutatni a hazai sportolói vándorlás irányait, tendenciáit és motivációs tényezöit. A statisztikai elemzés során foglalkozunk a hazai sportolók migrációs potenciáljának becslésével is. A tanulmány tanulsága szerint a magyar sportolói migráció a leggyakrabban a tölünk nyugatra fekvó európai országok felé irányul, míg hozzánk a volt "keleti blokk" országainak sportolói érkeznek.

\section{Bevezetés}

A sportolói migráció kezdetét gyakorlatilag a versenysport kialakulásának idejére tehetjük, amit többek között a sportban tapasztalható eredmény-centrikusság is előidézett.

Napjainkban is szenzációszámként közli a média, ha valamely sportolói kiválóság egyik csapatból - gyakran egyik országból - a másik csapatba - másik országba igazol, legtöbbször nehezen hihető pénzösszegekért. Ha belegondolunk, ez nem új jelenség hazánkban sem, hiszen már Puskás Ferenc is a Budapest Honvéd után a világhírủ Real Madrid labdarúgó csapatánál sportolt Spanyolországban.

A következókben arra teszünk kísérletet, hogy a sportolói vándorlásnál előforduló fogalmak tisztázása után bemutassuk a hazai sportolói migráció tendenciáit, irányait. Szekunder adatbázis konkrétan ebben a témakörben nem állt a rendelkezésünkre, így legtöbbször saját primer adatainkra támaszkodtunk, melynek egy részét a szakszövetségektöl gyüjtöttük, a másik - nagyobb - részét a doktori disszertációmhoz készített kérdőíves megkérdezés adatai szolgáltatták.

Kérdőíves kutatásunk adatbázisában a megkérdezett 1012 sportoló válaszai találhatók. A személyes lekérdezés eredményének tartjuk, hogy a kitöltött kérdőivek szinte kivétel nélkül alkalmasak voltak az értékelésre. Sportágakat tekintve a mintában találhatók: labdarúgók, kézilabdázók, kosárlabđázók, jégkorongozók, teniszezők, asztaliteniszezők, úszók, vívók, atléták, küzdősportolók. Vizsgálatunk az ország egész terü- 
Ács Pongrác : A sportolók területi mozgásai, avagy a sportolói vándorlás.

Tér és Társadalom 23. évf. 2009/3. 147-159. p.

letét lefedte, és nemcsak az élsportolókra korlátozódott, hanem három különbözö minősítésbe tömörítettük a válaszadókat, sportolókat. Így az adatbázisban első osztályú sportolók, másodosztályú sportolók és „hobby” sportolók találhatók. „Hobby” sportolónak tekintettük a minimum heti két alkalommal sportoló, de szakszövetségi igazolással nem rendelkező emberek csoportját.

Azt nem jelenthetjük ki, hogy a mintánk reprezentatív, mivel ahhoz ismerni kellene a Magyarország összes sportolójára vonatkozóan alapsokasági statisztikát - ilyen alapstatisztika nem létezik -, viszont mivel nagy mintánk van, ezért nagy mintás becslési tulajdonságokkal rendelkezünk. „Reprezentatívnak tekinthetjük azt a mintát, melynek legfontosabb jellemzői nem térnek el lényegesen a sokasság megfelelö jellemzőitől. Mindez azt is jelenti, hogy a reprezentativitás csupán viszonylagos lehet, függ a fontosnak tartott sokasági jellemzőktől és a mintavételt végző szakmai ismeretétől." (Pintér-Rappai 2001,8)

Elöző kutatásaink során bizonyitottuk, hogy egy terület gazdasága fejleszthető a sport közvetett és közvetlen tényezői által, melyek közül most a hazai sportolói vándorlás hatásait kívánjuk bemutatni. Hazai vándorlási adatokkal szinte minden statisztikai és demográfiai évkönyvben találkozhatunk, azonban a sportolók vándorlási adatait nem közli semmilyen kiadvány. Ezen azonban nem szabad meglepődni, hiszen a sport világában naponta ezrével keletkeznek adatok, azonban adatközlés szempontjából a statisztikának ez a része (sportstatisztika) még nagyon „gyermekcipőben" jár, hiszen még a hazai igazolt sportolók számára vonatkozó adatot sem találunk, így gyakran kell proxy mutatókat alkalmazni.

\section{A sportolói vándorlás alapfogalmai}

A sportban jelentkező vándorlási tendenciák és irányultságok nagyfokú hasonlóságot mutatnak a munkavállalási célból történő migrációs tendenciákkal, azonban az elején tisztázandó, hogy sport célú vándorlásról csak egy bizonyos sportolói szint (sportminőség) felett beszélhetünk, mely szint sportáganként változó.

Irányát tekintve megkülönböztetünk országhatáron belül vándorló sportolót (belföldi sportolói vándorlás) és országhatár(ok)on átívelő sportolói vándorlást (külföldi sportolói vándorlás). A múltban szinte kizárólag belföldi sportolói vándorlást regisztrálhattunk.

A kilencvenes évek elejéig külföldre csak az ún. mesterséges sportolói migráció volt megfigyelhetö, ami valamely kényszerítő körülmény miatt jött létre.

Spontán sportolói migrációval (önkéntes, belső elhatározás eredménye) a múltban nem nagyon találkozhattunk, hiszen tilos volt. Elmondhatjuk, hogy a kilencvenes évekig a sportolók többsége illegális vándorló volt. Erre a korszakra jellemzó, hogy hazánkban nagyon ritka volt a külföldi sportoló, hiszen „1984-ig a hazánkba bevándorlók száma évenként 1500 fö körül mozgott, ezt követỏen pedig 1984 és 1988 között 2200-2900 fö között volt. Ezeknek az adatoknak semmiféle «elvi» hátterét, megalapozottságát nem sikerült felfedezni, valószínủleg nem is volt." (Tóth 1997, 87) 
Ebben az idóben szintén kuriózum volt, ha hazai sportoló külföldi egyesületben sportolhatott.

A sportolói migráció iránya alapján:

- sportolói bevándorlásról akkor beszélünk, ha valamely külföldi sportoló sportolási célból valamely magyar egyesület színeiben az országhatáron belül sportol.

- kivándorló sportolónak azokat a hazai sportolókat nevezzük, akik a sporttevékenységüket külföldön végzik.

Hosszú távú sportolói vándorlásról akkor beszélhetünk, ha a sportoló a sportolási tevékenysége miatt legalább egy évre elköltözik - lakhelyet vált - egy másik településre, esetleg egy másik országba.

Rövid távú sportolói migráció jelentkezik, ha valamely sportoló egy évnél nem hosszabb időre egy másik egyesületben, településen sportol. Ez a fajta sportolói vándorlás legtöbbször nem jár együtt lakóhely változtatással, melynek a sportolók körében leggyakrabban megjelenő formája a sportolói ingázás. A vándorló sportolók életkora és a migráns népesség kor szerinti összetételében is hasonlóságot találhatunk, hiszen a migráló sportolók is többségében 15 és 39 év közöttiek (Hárs 2001). Ez visszavezethető arra, hogy a sportolók e korszakukban a legalkalmasabbak a kiemelkedő sportsikerek elérésére.

\section{Belföldi sportolói vándorlás}

A sportolók körében legrégebben fellelhetô vándorlási forma. Az élsport, látványsport megjelenése óta megfigyelhető, hogy a sportolók az országon belül gyakran változtatják a tartózkodási helyüket. Értelemszerủen adódik, hogy a sportolói migráció országon belül csak olyan települések között valósulhat meg, ahol a sportolók maguk is megtalálhatók.

Amennyiben a folyamatokat ábrázolni szeretnénk, akkor mindenképpen olyan egyesületeket, szakosztályokat kell keresnünk, ahol megfelelö minőségi sportról beszélhetünk, ahol megfelelö minőségủ sportolói képzés, nevelés folyik. Fontos megjegyezni, hogy a sportolói vándorlás sportágfüggő, vagyis nem mindegyik sportágban jelentkezik, és vannak sportágak, ahol egyáltalán nem jellemző. Felmerül a kérdés, hogy mely sportágakban és milyen mértékben találkozhatunk sportolói vándorlással?

Ezt a kérdést gazdasági oldalról kell megközelíteni, mivel leginkább azokban a sportágakban jelentkezik a migráció, ahol a sportolás mellett igen nagyfokú pénzmozgás is realizálódik, illetve a nagyobb szponzori körök is megjelennek (Pick, Fotex, MKB, Mol). Ezek azok a sportágak (pl. labdarúgás, kosárlabda, kézilabda, vízilabda), melyekben nagyon sikeresek vagyunk, illetve voltunk, vagy nagyon populárisak. Hazánkban elsődlegesen a labdajátékokban (csapatsportokban) találkozhatunk a legnagyobb sportolói migrációval. Itt jelentkeznek leginkább a sportgazdaság szereplöi, ezek a sportágak vannak leginkább a média középpontjában, és ők mozgatják meg a legtöbb nézőt is, vagyis kijelenthetjük, hogy csapatsportágak 
Ács Pongrác : A sportolók területi mozgásai, avagy a sportolói vándorlás.

Tér és Társadalom 23. évf. 2009/3. 147-159. p.

tekintetében az első osztályban, illetve a „professzionális” ligákban számszerüsíthetjük a legnagyobb sportolói vándorlást.

Amennyiben a sportolói sokaságból a legkisebb egységeket (sportolókat) nézzük, akkor a „tehetséges" sportolók (egyéni- és csapatsportág) körében jelentkezik leginkább a belföldi és a külföldi migráció. A tehetség definíciójával rengeteg helyen találkozunk, ezek közül Nádori (1976) definícióját emelnénk ki, aki (sport)tehetségen az ember meghatározott sajátosságainak összességét érti, vagyis sokféle kedvező feltételt valamely (sport)tevékenység végrehajtásához.

Ha a sportolói tehetségeknél valóban területi koncentrációval van dolgunk, akkor vizsgálandó, hogy mely motivációs tényezők felelősek ezért, illetve melyek azok a hazai települések, amelyek - a sporttehetségek megítélése szerint is - versenyképesnek számítanak.

Jelen tanulmányban a sportolói tehetségeket a Heraklész sportolók, illetve az olimpiai keret sportolókban értelmezzük, mivel azzal mindenki egyetért, hogy az adott sportágban biztosan tehetségesnek számít az a sportoló, aki a saját sportága tekintetében korosztályos válogatott (a Heraklész program tagja), majd késöbbiekben az olimpiai keret tagja. A Heraklész sportolók területi előfordulására vonatkozó adatbázist a Nemzeti Utánpótlás-nevelési Intézettől (NUPI) szereztük be, az olimpiai keret sportolókra vonatkozót az egyes sport-szakszövetségek nyilatkozatai alapján összegeztük. Vizsgálatunkat megyei (19 megye és a fỏváros) bontásban végeztük, és a területi koncentráció mértékét grafikusan (1. ábra) és területi egyenlötlenségi mutatók segítségével is megjelenítettük.

\section{1. ÁBRA}

A koncentráció grafikus ábrázolása (Lorenz- görbe) (The Graphical Representations of the Contentrations [Lorenz-curve])

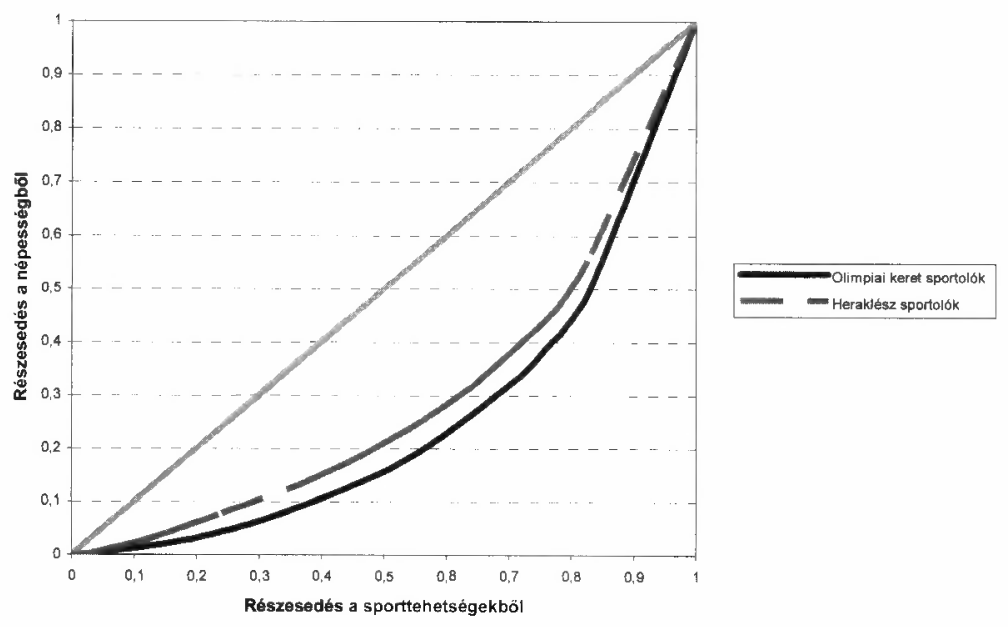

Forrás: Saját szerkesztés. 
$\mathrm{Az}$ 1. ábráról leolvasható, hogy nincs egyenlőség a sportolók területi elhelyezkedésében, sem a Heraklész, sem az olimpiai keret sportolók tekintetében, de teljes koncentrációról sem beszélhetünk. Az ábra azt is szemlélteti, hogy az olimpiai keret sportolók területi elhelyezkedésében nagyobb koncentráció tapasztalható. A görbe jól szemlélteti ugyan a területi koncentrációt, de számadattal nem szolgál a koncentráció nagyságáról. A koncentráció mértékét a Hirschmann-Herfindahl koncentrációsindex, illetve a Hoover-index segítségével vizsgáltuk.

$$
\begin{aligned}
& K_{1}=\sum_{i=1}^{n}\left(\frac{x_{i}}{\sum_{i=1}^{n} x_{i}}\right)^{2}=0,265 \\
& \mathrm{X}_{\mathrm{i}}=\mathrm{a} \text { naturális mértékegység- } \\
& \text { ben megadott területi jellemzö } \\
& \mathrm{az}_{\mathrm{i}} \text { területegységben. } \\
& \mathrm{Y}_{\mathrm{i}}=\text { a naturális mértékegység- } \\
& \text { ben megadott területi jellemző } \\
& \mathrm{K}_{2}=\sum_{i=1}^{n}\left(\frac{y_{i}}{\sum_{i=1}^{n} y_{i}}\right)^{2}=0,211
\end{aligned}
$$

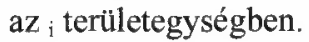

A Hirschmann-Herfindahl koncentrációs index számított értékei megmutatják, hogy az olimpiai keret sportolók területi koncentráltsága $\left(\mathrm{K}_{1}\right)$ nagyobb, mint a Heraklész sportolóké $\left(\mathrm{K}_{2}\right)$, de az bizonyos, hogy a területek (megyék) közül egyik sincs monopol helyzetben.

Hasonló eredményt hozott a Hoover-index segitségével elvégzett számítás is.

$$
\begin{aligned}
& H_{1}=\frac{\sum_{i=1}^{n}\left|x_{i}-f_{i}\right|}{2}=38 \% \\
& H_{2}=\frac{\sum_{i=1}^{n}\left|y_{i}-f_{i}\right|}{2}=32 \%
\end{aligned}
$$

Itt $x_{i}, y_{i}$ és $f_{i}$ megoszlási viszonyszámot jelöl.

A Heraklész sportolók 32\%-át, az olimpiai keret sportolók 38\%-át kellene átcsoportosítanunk, hogy a lakónépesség területi eloszlásával azonos legyen az eloszlásuk, vagyis a sportolói tehetségekben, mint a migrációs sokasság legkisebb egységeiben (egyedeiben) területi egyenlótlenséget, koncentrációt tapasztalunk.

Az egyenlőtlenségek kialakulásáért felelős motivációs tényezőket a kérdőíves kutatásunk eredményei alapján ismertetjük (2.ábra).

Kérdőives kutatásunk kapcsán bizonyítást nyert az az - eddig csak evidenciaként kezelt - tény, hogy a lakhelyváltást befolyásoló tényezők közül a legfontosabbnak a jobb anyagi megbecsülést tartják a migráló sportolók, melyet az erősebb bajnokságban való szereplés lehetősége követ. A település sporttörténelme bizonyult a legkevésbé fontos tényezőnek a lakhelyváltást befolyásoló tényezők közül. 
Ács Pongrác : A sportolók területi mozgásai, avagy a sportolói vándorlás.

Tér és Társadalom 23. évf. 2009/3. 147-159. p.

\section{2. ÁBRA}

A lakhelyváltozást befolyásoló tényezök

(Influencing Factors of Moving Homes)

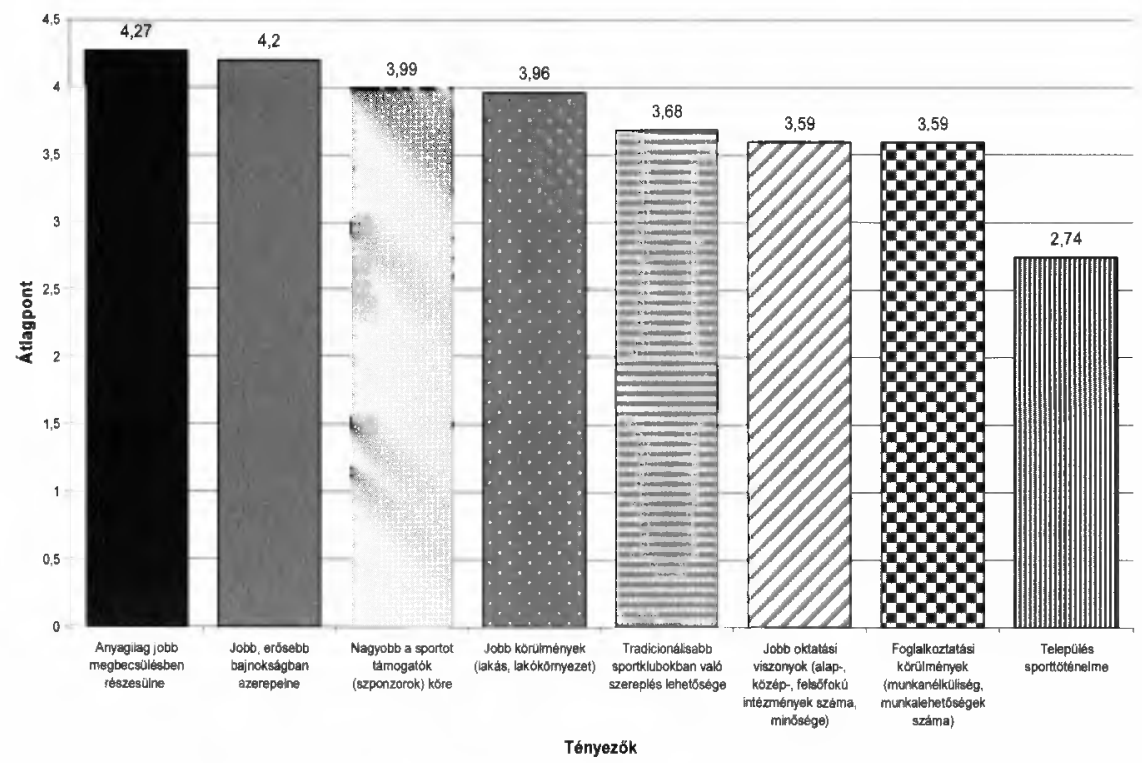

Forrás: A kérdőives felmérés alapján saját szerkesztés.

\section{3. ÁBRA}

A sportolók által felállitott területi versenyképességi sorrend

(Regional Competitiveness Order)

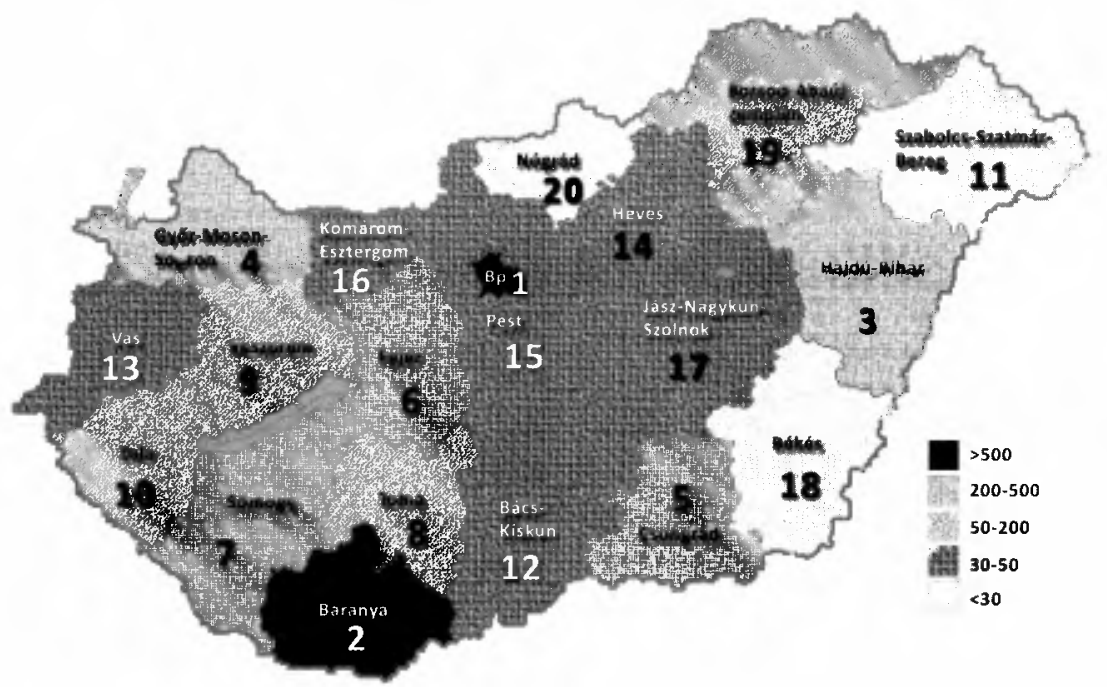

Forrás: A kérdőives felmérés alapján saját szerkesztés. 
A 3. ábra, szintén a kérdőíves kutatásunk eredményeit felhasználva, bemutatja a sportolók által felállított hazai területi versenyképességi sorrendet. Az ábra azt hivatott szemléltetni, hogy a sportolók mely megyéket részesítik elönyben a belföldi migráció tekintetében.

A térképen látható, hogy az ország nyugati megyéi a sportolók véleményei alapján versenyképesebbek, mely alól kivételt képez az ország két keleti megyéje: HajdúBihar és Csongrád.

\section{Külföldi sportolói vándorlás}

A múltban a külföldre igazolás óriási procedúrával járt, mondhatni tilos volt, a változás a kilencvenes évek derekán történt.

Jean-Marc Bosman nevéhez köthetó az EU sportszabályozásának legfontosabb eleme, a sportolók egyéb munkavállalókhoz hasonló szabad mozgásának megteremtése. Másfél évtizede, 1990 júniusában Bosmannak a belga RFC Liége játékosaként lejárt a szerződése, klubja azonban pénzt követelt érte. A vevő, a francia másodosztályú Dunkerque nem fizetett, Bosman szerzỏdés nélkül maradt. Beperelte a Liége-t és a belga szövetséget, mert megsértették az EU alapokmányának számító Római Szerződésnek a szabad munkaerő-áramlásról szóló 48. cikkelyét. Végigjárt minden lépcsőfokot, végül 1995. december 15-én a Luxembourgban székelő Európai Bíróság C-415/93 számú határozatában kimondta a sportolók szabad mozgását, amely két tényezőt foglal magában:

Egyrészt a lejárt szerződésủ sportolókért kért transzferdíj eltörlését, másrészt az idegenlégiósok számát korlátozó szabályok eltörlését, idegenlégiós alatt egyelőre az Unió állampolgárait értve. (Bosman csak a transzferdíj eltörléséért harcolt, de a bíróság az ügy vizsgálata kapesán döntött az idegenlégiós-korlátozás felöl is.)

Ettôl az idóponttól kezdve könnyebb a sportolóknak is külföldre igazolniuk, külföldre vándorolniuk.

Korábbi kutatásaink során szignifikảns kapcsolatot találtunk a sportági minősítés és a vándorlás időtartama között, melyet több mélyinterjú alanyunk is megerösített. Erre a kutatásra támaszkodva (2005a; 2005b) mutatjuk be a következó fogalmakat és összefüggéseket:

- A rövid távú sportolói vándorlás leginkább az alacsony osztályokban figyelhető meg, itt a sportolók többnyire „gyors és könnyü” pénzszerzés céljából mennek külföldre sportolni, illetve a volt „elit sportolóink” külhonban fejezik be aktív pályafutásukat. Ennek a tevékenységnek km-ben kifejezhetô gazdaságossági határa is van, mivel ezek a sportolók csak a mérkỏzéseiket játsszák le külföldön, őket nevezhetjük ingázóknak is. A sportolók elbeszélései alapján ez a távolság egy $\mathrm{kb} .1500 \mathrm{~km}$ sugarú körben becsülhető meg, hiszen ennél távolabb rövid távú sportolói migrációval elvétve találkozhatunk. A hazai sportolók leggyakrabban a szomszédos Ausztria vagy Németország közeli városaiban sportolnak, és itt alacsonyabb osztályban is - a hazai viszonyokhoz 
Ács Pongrác : A sportolók területi mozgásai, avagy a sportolói vándorlás.

Tér és Társadalom 23. évf. 2009/3. 147-159. p.

képest - jól keresnek. Régebben (öt, hat évvel ezelőtt) a sportolók kizárólag személygépkocsikkal igáztak, manapság gyakran találkozunk olyan sportolókkal is, akik a hétvégi mérkőzéseikre már repülögéppel, legtöbbször ún. „fapados" járatokkal utaznak. A rövid távú migrációnak egy speciális esete, amikor a játékost elcserélik, vagy egy évre kölcsönadják egy hazai vagy külföldi egyesületnek. Az ilyen jellegủ rövid távú sportolói vándorlásnak az elsődleges célja, hogy a fiatal sportolók több játéklehetöséghez jussanak, vagyis fejlödjenek.

- A hosszú távú sportolói migrációnak a pénzkereset mellett a sportszakmai fejlödés is a célja. A sportolók évközben is kint élnek - többnyire az adott egyesület által biztosított lakásosokban -, és a szakosztály napi edzésein aktívan részt vesznek. Életkorukat tekintve fiatalabbak, mint a rövid távú vándorlók. Őket nevezhetjük az igazán profi sportolóknak. Itt már távolabbi célállomások is megjelenhetnek.

A kérdőíves kutatásunk során megállapítottuk, hogy a külföldi és belföldi migrációt elöidéző motivációs tényezőkben nincs különbség, hiszen itt is elsősorban az anyagi és másodsorban a sportfejlődési tényező játszik kulcsszerepet.

Érdekesebb eredményt kaptuk, amikor a külföldre vándorlást gátló tényezőkröl kérdeztük a sportolókat (4. ábra).

A sportolók leginkább a családi kötelék miatt $(41 \%)$ nem vándorolnak külföldre. Láthatóan magas értéket mutat $(15 \%)$ a sportolóknál a nyelvtudás hiánya, melyet a szándék hiánya (13\%), mint gátló tényező követ (4. ábra).

\section{4. ÁBRA}

A külföldre igazolást gátló tényezök százalékos megoszlása

(Preventing Factors of Transferring Abroad in \%)

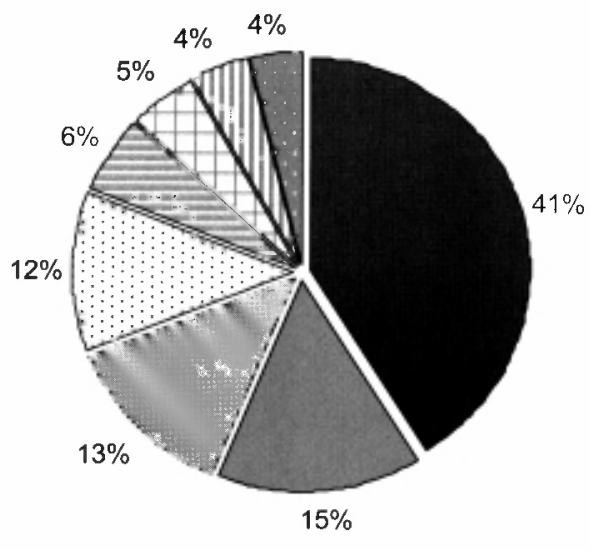

Családi-, társas kötelék

Nyelvtudás hiánya

Szándék hiánya

Pénzügyi helyzet, anyagi gondok

$\square$ Végzettség el nem ismerése

$\square$ Bajnokság minösége

Adózási különbségek

Adminisztráció, formaságok

Forrás: A kérdőíves felmérés alapján saját szerkesztés. 
Ács Pongrác : A sportolók területi mozgásai, avagy a sportolói vándorlás.

Tér és Társadalom 23. évf. 2009/3. 147-159. p.

TÉT XXIII. évf. 2009

Gyors ténykép

155

Érdekes, szignifikáns kapcsolatot számszerüsítettünk, amikor a sportági minösités és a sportolók külföldre vándorlási hajlandóságát vizsgáltuk (1. táblázat). A mutatószám relatíve alacsony értéke (Cramer $\mathrm{C}=0,187$ ) is értelemszerüen szignifikáns értéket mutat, hiszen nagy mintánk van.

\section{TẢBLÁZAT}

Külföldre igazolási hajlandóság és a minösités kereszttáblája

(The Crosstable of the Willingness to Transfer Abroad and the Qualifications)

\begin{tabular}{|c|c|c|c|c|c|c|}
\hline & & & \multicolumn{3}{|c|}{ Sportági minősités } & \multirow[b]{2}{*}{ Összesen } \\
\hline & & & $\begin{array}{c}\text { Elsö } \\
\text { osztályú }\end{array}$ & $\begin{array}{l}\text { Másod } \\
\text { osztályú }\end{array}$ & $\begin{array}{c}\text { Hobby } \\
\text { sportoló }\end{array}$ & \\
\hline \multirow{9}{*}{ 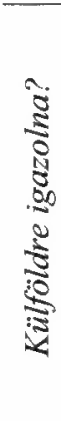 } & & Gyakoriság & 70 & 125 & 329 & 524 \\
\hline & $\mathrm{Nem}$ & Várható gyakoriság & 92,4 & 149 & 282,5 & 524 \\
\hline & & \% minösitésen belül & $39,3 \%$ & $43,6 \%$ & $60,5 \%$ & $51,9 \%$ \\
\hline & & Gyakoriság & 108 & 162 & 215 & 485 \\
\hline & Igen & Várható gyakoriság & 85,6 & 138 & 261,5 & 485 \\
\hline & & \% minösitésen belül & $60,7 \%$ & $56,4 \%$ & $39,5 \%$ & $48,1 \%$ \\
\hline & & Gyakoriság & 178 & 287 & 544 & 1009 \\
\hline & Összesen & Várható gyakoriság & 178 & 287 & 544 & 1009 \\
\hline & & $\%$ minösitésen belül & $100 \%$ & $100 \%$ & $100 \%$ & $100 \%$ \\
\hline
\end{tabular}

Forrás: A kérdőives felmérés alapján saját számítás.

Látható, hogy a sportági minősítések javulásával a külföldre igazolás hajlandósága is emelkedik. Tehát az élsportolóink nagyobb mértékben változtatnák meg a lakhelyüket, hiszen az ő „termékük”, tudásuk keresettebb külföldön is.

A primer adatbázist felhasználva arra vállalkoztunk, hogy megbecsüljük a hivatásos sportolók arányát 95\%-os megbízhatósági szint mellett.

Számításainkat a következtetéses statisztikából ismert sokasági aránybecslés módszerével tettuik meg. Az átlag becsléséhez hasonlóan becsülhető az alapsokaság valamilyen ismérv szerinti aránya (megoszlási viszonyszáma) is. Valamely tulajdonsággal bíró egyedek arányát jelöljük az alapsokaságban $P$-vel. A $P$ arány pontbecslése:

$$
p=\frac{k}{n}
$$

ahol: $k$ az adott tulajdonsággal bíró egyedek száma.

Vagyis a saját adatbázisunkban ez az érték: $0,261=\frac{264}{1012}$ 
A mintabeli aránynak a mintából számítható standard hibája:

$$
\begin{aligned}
& \sigma_{p}=\sqrt{\frac{p(1-p)}{n}} \\
& \sigma_{p}=\sqrt{\frac{p(1-p)}{n}\left(1-\frac{n}{N}\right)} \\
& \sigma_{p}=\sqrt{\frac{0,261(1-0,261)}{1012}}
\end{aligned}
$$

Belátható, hogy a korrekciós tényezőtől $\left(1-\frac{n}{N}\right)$ a jelen esetben eltekinthetünk, mivel ez nagy valószínủséggel egyhez közeli értéket ad!

Nagy minta (ahol $n \geq 30$ ) esetén joggal feltételezzük, hogy $p$ eloszlása közelíthető a normális eloszlással, ezért a konfidenciaintervallum szerkesztéséhez felhasználhatjuk a standard normális eloszlás értékeit.

A konfidenciaintervallum: $\mathrm{p} \pm \mathrm{z} \times \sigma_{\mathrm{p}}$

$$
0,261 \pm 1,96 \times \sqrt{\frac{0,261 \times 0,739}{1012}}
$$

$0,261 \pm 0,027$

Tehát 95\%-os megbízhatóság mellett állítható, hogy a sportolók 23,4 és 28,8\%-ban mutatnak migrációs hajlandóságot. Ezt az adatot nevezzük a magyar élsportolók külföldi migrációs hajlandóságának. Fontos megemlíteni, hogy a tényleges külföldre költtözési hajlandóság és az elméleti szándék (migrációs potenciál) ${ }^{2}$ ritkản esik egybe.

Természetesen Magyarország a sportban is nem csak, mint kibocsátó, hanem mint befogadó ország is megjelenik.

Adatgyüijtésünk során nehezitỏ körülmény volt, hogy a legtöbb országos sportszövetségben sem elektronikusan, sem kézzel nem készítettek erre vonatkozóan csoportositó statisztikai táblázatokat. Az itt feltüntet adatokat magam gyüjtöttem és összegeztem a szakszövetségi átigazolási papírok átolvasása, összegzése alkalmával, miközben arra a kérdésre kerestem a választ, hogy kik lehetnek (milyen nemzetiségủek) azok a sportolók, akik Magyarországot választják „célországnak”, és milyen motivációval érkeznek hazánkba?

A kezdeti hipotéziseink egyike az volt, hogy a volt „keleti blokk” sportolói érkeznek hozzánk a legnagyobb számban, és a csapatsportágakban a leggyakoribb az elöfordulásuk. 
Vizsgálatunk fényt deritett arra, hogy a külföldi sportolók két fő ok miatt érkeznek hazánkba:

a) jobb megélhetésben bíznak (magasabb kereseti lehetóség),

b) ugródeszkának tekintik országunkat.

Vannak külföldi sportolók, akik abban reménykednek, hogy Magyarországról könnyebben tudnak nyugat-európai országokba igazolni; a külföldi labdarúgók negyede gondolkodott így (Ács 2007).

A három leginkább migrációra hajlamos csapatsportág (labdarúgás, kosárlabda, kézilabda) segítségével próbáljuk bemutatni a sportolók vándorlási irányait (5. ábra).

Megállapíthatjuk, hogy a magyar sportolók leginkább a tólünk nyugati országokat választják sportolásuk lehetséges helyszínének, tehát a gazdasági jólétnek pozitiv hatása van a sportolók vándorlására. A térkép elárulja nekünk - hipotézisünk igazolásaként -, hogy Magyarországot a legnagyobb számban a tőlünk keletre eső országok részesítik előnyben a vizsgált három sportág esetében. Létezik azonban egy kivétel is, a kosárlabda, mely sportág esetében jóval erősebb bajnokságból érkeznek hozzánk sportolók, egyértelmúen pénzkereseti céllal. Érdemes lenne számszerüsíteni, hogy az egyes országokban az adott sportágak minöségi különbsége miként befolyásolja, hogy az ország az adott sportágban kibocsátó vagy befogadó lesz.

\section{5. ÁBRA}

A sportolók vándorlásának iránya (2005/2006)

(The Direction of Sports People's Migration, 2005/2006)

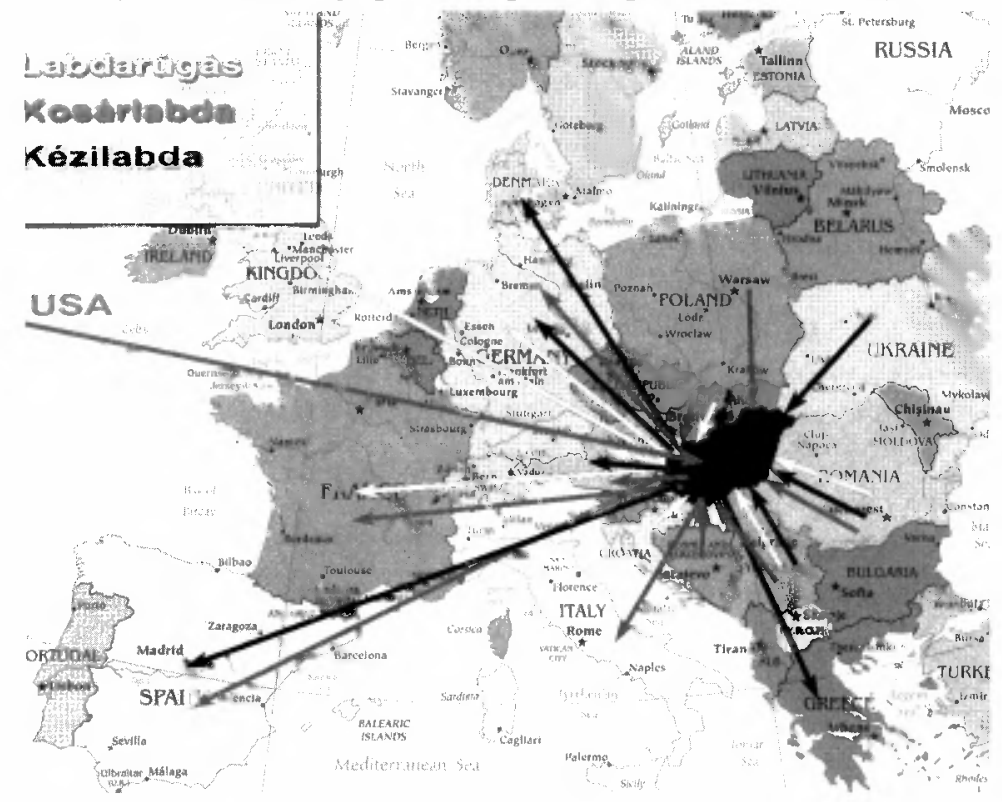

Forrás: Saját szerkesztés. 
Ács Pongrác : A sportolók területi mozgásai, avagy a sportolói vándorlás.

Tér és Társadalom 23. évf. 2009/3. 147-159. p.

\section{Összegzés}

Jelen tanulmányban a migráció széles körủ irodalmát egy újszerú, eddig még nem publikált résszel, a sportolói vándorlás jellemzőivel, hazai tendenciáival egészítettük ki. Napjainkban, a médiában is gyakran elhangzó sportolói migráció fogalomtárának bemutatásán túl, igyekeztünk a vándorlást elöidézö, illetve gátló tényezőkre is felhívni a figyelmet. Megpróbáltuk a sportolók külföldi migrációs potenciálját megbecsülni, mely szerint szinte minden negyedik élsportoló vállalná a külföldre vándorlást. Igazoltuk azt az evidenciaként kezelt tényt, hogy a hazai sportolók legszívesebben a tölünk nyugatra fekvő európai országokat részesítik előnyben, míg hozzánk a volt „keleti blokk” sportolói érkeznek. Kérdöives kutatásunk eredményei által láthatóvá vált, hogy az anyagi biztonság, jobb kereseti lehetőség a legnagyobb motivációs tényezö, míg a leginkább gátló tényezỏnek a családi kötelék számít.

Véleményünk szerint a sportolók térbeli mozgása a lakosság térbeli mozgását (egy-egy sportesemény megtekintése) is alkalmanként elöidézheti, melyet a sportturizmus, mint passzív sportturizmus definiál. Ismeretes, hogy a nagyobb nemzetközi sporteseményeknek pozitív hatása lehet egy terület gazdaságára is.

\section{Jegyzetek}

' Jelen tanulmány elhangzott szóban az Andorka Rudolf Társadalomtudományi Társaság, a Budapesti Corvinus Egyetem Szociológiai és Társadalompolitikai Intézete, valamint a Magyar Statisztikai Társaság Demográfiai szakosztálya által „Migráció - társadalmi összefüggések” címmel rendezett konferencián, 2007. október 19-én a Corvinus Egyetemen.

2 A migrációs potenciál egy ország népességének vagy valamely kisebb társadalmi csoportjának térbeli elmozdulási szándékainak mértéket fejezi ki. Ez valójában egy egyszerủ statisztikai arányszám, amely azt fejezi ki, hogy az adott népesség hány százalékának vannak migrációs tervei.

\section{Irodalom}

Ács P. (2005a) A sportolói migráció és annak lehetőségei az EU-csatlakozásunk tükrében. - BudaySántha A.-Erdósi F.-Horváth Gy. (szerk.) Évkönyv 2004-2005. PTE RKK Regionális Politika és Gazdaságtan Doktori Iskola, Pécs. 288-298. o.

Ács, P. (2005b) Migration der ungarischen Sportler. - Fehér I. (szerk.) III. Erdei Ferenc Tudományos Konferencia. Kecskeméti Föiskola, Kecskemét. 1108-1113. o.

Ács P. (2007) A magyar sport területi versenyképességének helyzetfeltáró empirikus vizsgálata. Doktori értekezés, PTE RKK Regionális Politika és Gazdaságtan Doktori Iskola, Pécs.

Hárs Á. (2001) Népességmozgások Magyarországon a XXI. század küszöbén. - Lukács É.-Király M. (szerk.) Migráció és az Európai Unió. Szociális és Családügyi Minisztérium, Budapest.

Kerékgyártó Gy.-Mundruczó Gy.-Sugár A. (2001) Statisztikai Módszerek és alkalmazásuk. Aula Kiadó, Budapest.

Köves P.-Párniczky G. (1981) Általános Statisztika I. Közgazdasági és Jogi Könyvkiadó, Budapest.

Lukács É.-Király M. (szerk.) (2001) Migráció és az Európai Unió. Szociális és Családügyi Minisztérium, Budapest

Nádori L. (1976) Edzéselmélet és módszertana. Főiskolai tankönyv. Sport, Budapest.

Nemes Nagy J. (2005) Regionális elemzési módszerek. Regionális Tudományi Tanulmányok 11. MTA ELTE Regionális Tudományi Kutatócsoport, Budapest. 
Pintér J.-Rappai G. (2001) A mintavételi tervek készítésének néhány gyakorlati megfontolása. - Marketing \& Menedzsment. 4. 4-11. o.

Pintér J.-Rappai G. (2007) Statisztika. Pécsi Tudományegyetem Közgazdaságtudományi Kar, Pécs.

Pintér J.-Ács P. (2006) Bevezetés a sportstatisztikába. Dialóg Campus Kiadó, Budapest-Pécs.

Sik E.-Simonovics B. (2002) Migrációs potenciál Magyarországon 1993-2001. - Kolosi T.-Tóth I.Gy.Vukovich Gy. (szerk.) Társadalmi Riport 2002. TÁRKI, Budapest.

Tóth P.P. (1997) Haza csak egy van? Menekültek, bevándorlók, új állampolgárok Magyarországon (1988-1994). Püski, Budapest. 